\title{
Kepatuhan Menggunakan Alat Pelindung Diri (APD) Ditinjau dari Pengetahuan dan Perilaku pada Petugas Instalasi Pemeliharaan Sarana Dan Prasarana Rumah Sakit (IPSRS)
}

\author{
$\underline{\text { Rizka Ayu Zahara }}{ }^{1}$, Santoso Ujang Effendi $^{2}$, Nurul Khairani ${ }^{3}$ \\ Program Studi S-1 Kesehatan Masyarakat STIKES Tri Mandiri Sakti Bengkulu, ${ }^{1,2,3}$ \\ Jl. Hibrida Raya No. 03 Kelurahan Sidomulyo Kota Bengkulu 38229 \\ Email: rizka.zahara23@gmail.com ${ }^{1}$,santos_ue@yahoo.com ${ }^{2}$,nrlkhairani@yahoo.com ${ }^{3}$
}

\begin{abstract}
ABSTRAK
Alat Pelindung Diri (APD) berfungsi untuk melindungi tubuh terhadap bahaya-bahaya kecelakaan kerja dan mengurangi tingkat keparahan dari kecelakaan kerja yang terjadi. Penelitian ini bertujuan untuk mengetahui korelasi antara pengetahuan dan perilaku petugas Instalasi Pemeliharaan Sarana dan Prasarana Rumah Sakit (IPSRS) dengan kepatuhan terhadap penggunaan Alat Pelindung Diri (APD). Desain penelitian ini adalah Cross Sectional. Populasi adalah seluruh petugas IPSRS di RSUD Siti Aisyah Kota Lubuklinggau sebanyak 64 orang. Penelitian dilaksanakan pada bulan Agustus 2017. Analisis data menggunakan uji statistik chi-Square. Hasil penelitian menunjukkan adanya korelasi antara kepatuhan menggunakan Alat Pelindung Diri APD pengetahuan ( $p$ value $=0$, 001), dan perilaku $(p$ value $=0$, 006). Pihak RSUD diharapkan dapat menerapkan Standar Prosedur Operasional (SPO) yang lebih tegas, melakukan pelatihan tentang penggunaan APD, dan meningkatkan pengawasan terhadap kepatuhan petugas dalam menggunakan APD.
\end{abstract}

Kata Kunci: Pengetahuan, Perilaku, Kepatuhan, Alat Pelindung Diri (APD).

ADHERENCE USING PERSONAL PROTECTIVE EQUIPMENT (PPE) IN TERMS OF THE KNOWLEDGE AND BEHAVIOR OF OFFICER INSTALLATION MAINTENANCE FACILITIES AND INFRASTRUCTURE HOSPITAL (IPSRS)

\begin{abstract}
Personal Protective Equipment (PPE) serves to protect the body against occupational injuries and reduce the severity of work accidents that occur. This study aims to determine the correlation between the knowledge and behavior of the officer of the Installation of Hospital Facilities and Infrastructure Maintenance (IPSRS) with the adherence to the use of Personal Protective Equipment (PPE). The design of this study was Cross Sectional. The population is all IPSRS officers in RSUD Siti Aisyah Lubuklinggau City as many as 64 people. The study was conducted in August 2017. The data analysis used chi-square statistical test. The results showed that there was a correlation between adherence using Personal Protective Equipment PPE with knowledge ( $p$ value =0, 001), and behavior ( $p$ value $=0$, 006). The RSUD is expected to apply more strict Standard Operating Procedures $(S O P)$, conduct training on the use of PPE, and improve supervision of officers' compliance in using PPE.
\end{abstract}

Keywords: Knowledge, Behavior, Adherence, Personal Protective Equipment (PPE)

How to Cite: Zahara, R. A; Effendi, S. U; Khairani, Nurul. (2017). Kepatuhan Menggunakan Alat Pelindung Diri (APD) Ditinjau dari Pengetahuan dan Perilaku pada Petugas Instalasi Pemeliharaan Sarana Dan Prasarana Rumah Sakit (IPSRS). Jurnal Aisyah: Jurnal Ilmu Kesehatan. 2 (2), 153 - 158. 


\section{PENDAHULUAN}

Rumah Sakit sebagai institusi pelayanan kesehatan bagi masyarakat dengan karakteristik tersendiri yang dipengaruhi oleh perkembangan ilmu pengetahuan kesehatan, kemajuan teknologi, dan kehidupan sosial ekonomi masyarakat yang harus tetap mampu meningkatkan pelayanan yang lebih bermutu dan terjangkau oleh masyarakat agar terwujud derajat kesehatan yang setinggi-tingginya (Kemenkes RI, 2010).

Dalam Undang-Undang Nomor 36 Tahun 2009 tentang Kesehatan, khususnya pasal 165: "Pengelola tempat kerja wajib melakukan segala bentuk upaya kesehatan melalui upaya pencegahan, peningkatan, pengobatan dan pemulihan bagi tenaga kerja". Berdasarkan pasal tersebut, maka pengelola tempat kerja di Rumah Sakit mempunyai kewajiban untuk menyehatkan para tenaga kerjanya. Salah satunya adalah melalui upaya kesehatan dan keselamatan.

Kecelakaan kerja adalah kecelakaan yang terjadi berhubungan dengan kerja, termasuk penyakit yang timbul karena hubungan kerja, demikian pula kecelakan yang terjadi dalam perjalanan ke dan dari tempat kerja. Kecelakaan kerja merupakan kejadian tidak terduga dan tidak diinginkan baik kecelakaan akibat langsung pekerjaan maupun kecelakaan yang terjadi pada saat pekerjaan (Buntarto, 2015).

Pengendalian bahaya bisa dilakukan dengan berbagai cara, salah satunya adalah dengan menggunakan alat pelindung diri (APD). APD merupakan suatu alat yang dipakai untuk melindungi diri atau tubuh terhadap bahaya-bahaya kecelakaan kerja, dimana secara teknis dapat mengurangi tingkat keparahan dari kecelakaan kerja yang terjadi. Peralatan pelindung diri tidak menghilangkan atau mengurangi bahaya yang ada, peralatan ini hanya mengurangi jumlah kontak dengan bahaya dengan cara penempatan penghalang antara tenaga kerja dengan bahaya (Suma'mur, 2009).
California State Departement of Industrial Relations menuliskan rata-rata kecelakaan di rumah sakit menyebabkan 17 hari kerja yang hilang per 100 karyawan karena kecelakaan. Karyawan yang sering mengalami cedera, antara lain: perawat, karyawan dapur, pemeliharaan alat, laundry, cleaning service, dan teknisi. Penyakit yang biasa terjadi antara lain: hipertensi, varises, anemia, ginjal (karyawan wanita), dermatitis, low back pain, saluran pernapasan, dan saluran pencernaan (Hasyim, H. 2015).

Bahaya-bahaya potensial di Rumah Sakit yang disebabkan oleh faktor biologi (virus, bakteri, jamur, parasit); faktor kimia (antiseptik, regent, gas anastesi); faktor ergonomi (lingkungan kerja, cara kerja, dan posisi kerja yang salah); faktor fisik (suhu, cahaya, bising, listrik, getaran dan radiasi); faktor psikologi (kerja bergilir, beban kerja, hubungan kerja, hubungan sesama pekerja/atasan) dapat menyebab- kan penyakit akibat kerja.

Bagian pemeliharaan terpajan dengan solvent, asbes, listrik, bising, dan panas. Karyawan di bagian cleaning service terpajan deterjen, desinfektan, tertusuk sisa jarum suntik dan lain-lain. Karyawan katering sering mengalami tertusuk jari, luka bakar, terpeleset, keletihan, stress kerja, dan lain-lain. Teknisi radiologi potensial terpapar radiasi dari sinar $\mathrm{X}$ dan radioaktif isotop atau zat kimia lainnya. Perawat sering cedera punggung, terpajan zat kimia beracun, radiasi, dan strss akibat shift kerja. Petugas di ruang operasi mempunyai risiko masalah reproduksi atau gastroenterologi risiko masalah limbah gas anastesi, risiko luka potong-tusuk, radiasi dan lain-lain.

Menurut Geller (2001) pada teori safety triad, kepatuhan (compliance) merupakan salah satu faktor pada komponen behaviour yang dipengaruhi oleh interaksi faktor pada komponen person dan environtment (Notoatmodjo, S. 2010). 


\section{Jurnal Aisyah: Jurnal Ilmu Kesehatan 2 (2) 2017, - 155}

Rizka Ayu Zahara, Santoso Ujang Effendi, Nurul Khairani

Data laporan kasus kecelakan kerja yang tercatat di RSUD Siti Aisyah Kota Lubuklinggau selama tahun 2016 diketahui 1 kasus kecelakaan kerja terjadi pada bulan Januari, 2 kasus terjadi pada bulan maret, 2 kasus terjadi pada bulan Mei, dan 5 kasus terjadi di bulan Agustus. Dari 10 kasus kecelakaan kerja yang dilaporkan terjadi di RSUD Siti Aisyah Kota Lubuklinggau diketahui 8 kasus kecelakaan kerja dialami oleh petugas IPSRS dan 2 kasus kecelakaan kerja lainnya dialami oleh perawat, dan sampai dengan awal bulan Mei 2017 tercatat 2 kasus kecelakaan kerja terjadi pada bulan Januari 2017, 2 kasus terjadi pada bulan April dan 1 kasus terjadi di awal bulan Mei 2017.

Berdasarkan hal tersebut diatas maka peneliti tertarik untuk mengetahui korelasi antara Kepatuhan Menggunakan Alat Pelindung Diri (APD) dengan Pengetahuan dan Perilaku pada Petugas Instalasi Pemeliharaan Sarana Dan Prasarana Rumah Sakit (IPSRS)

\section{METODE PENELITIAN}

Jenis penelitian ini adalah penelitian Observasional dengan desain Cross Sectional. Variabel independent terdiri dari pengetahuan dan perilaku, sedangkan variabel dependent adalah kepatuhan penggunaan APD. Populasi yang digunakan dalam penelitian ini adalah seluruh petugas IPSRS RSUD Siti Aisyah Kota
Lubuklinggau yang berjumlah 64 orang. Sampel sebanyak 64 orang petugas. Teknik pengambilan sampel adalah total sampling. Lokasi penelitian di RSUD Siti Aisyah Kota Lubuklinggau yang dilaksanakan pada bulan Agustus 2017. Data yang digunakan adalah data primer yang diperoleh melalui observasi dan wawancara dan data sekunder diperoleh dari RSUD Siti Aisyah Kota Lubuklinggau dan buku-buku referensi lainnya. Analisis data dengan analisis univariat untuk melihat distribusi dan frekuensi variabel dependent dan independent dan analisis bivariat untuk mengetahui hubungan antara variabel pengetahuan dan perilaku dengan kepatuhan penggunaan APD yang dianalisis dengan uji Chi-Square ( $\left.\chi^{2}\right)$ dengan nilai $\alpha=$ 0,05 , dengan ketentuan yang berlaku yaitu bila $p$-value $\leq \alpha(0,05)$, maka ada hubungan yang bermakna antara variabel dan variabel dependent. Bila bila $p$-value $\geq$ $\alpha(0,05)$ maka tidak ada hubungan yang bermakna antara variabel independent dan variabel dependent.

\section{HASIL DAN PEMBAHASAN}

Analisis univariat dilakukan pada tiap variabel penelitian. Pada umumnya dalam analisis ini hanya menghasilkan distribusi dan persentase dari tiap variabel penelitian (Putri; K. Denny, Y. 2014). Berikut akan disajikan analisis univariat dari masingmasing variabel:

Tabel 1. Hubungan Pengetahuan dengan Kepatuhan Penggunaan APD

\begin{tabular}{|c|c|c|c|c|c|c|c|}
\hline \multirow{3}{*}{ Pengetahuan } & \multicolumn{7}{|c|}{ Kepatuhan Penggunaan APD } \\
\hline & \multicolumn{2}{|c|}{ Tidak Patuh } & \multicolumn{2}{|c|}{ Patuh } & \multirow{2}{*}{ Jumlah } & \multirow{2}{*}{ Prosentase } & \multirow{2}{*}{ p value } \\
\hline & Jumlah & Prosentase & Jumlah & Prosentase & & & \\
\hline Kurang & 12 & 92,3 & 1 & 7,7 & 13 & 100 & \multirow{4}{*}{0,001} \\
\hline Cukup & 12 & 63,2 & 7 & 36,8 & 19 & 100 & \\
\hline Baik & 11 & 34,4 & 21 & 65,5 & 32 & 100 & \\
\hline Jumlah & 35 & 54,7 & 29 & 45,3 & 64 & 100 & \\
\hline
\end{tabular}

Berdasarkan hasil penelitian, diketahui bahwa distribusi frekuensi responden yang tidak patuh dalam menggunakan lebih besar, yaitu 54,7\% dibandingkan dengan petugas yang patuh dalam menggunakan APD, yaitu 45, 3\%. Untuk distribusi frekuensi mengenai pengetahuan ada sebesar 50, $0 \%$ petugas memiliki 
pengetahuan yang baik, 29, 7\% petugas memiliki pengetahuan cukup dan 20,3\% petugas memiliki pengetahuan kurang. Petugas yang berperilaku baik sebesar $87,5 \%$, sedangkan petugas yang berperilaku tidak baik sebesar $12,5 \%$.

Analisis bivariat, analisis ini dilakukan untuk melihat hubungan antara variabel independent (pengetahuan dan perilaku) dengan variabel dependent (kepatuhan penggunaan APD), melalui uji Chi Square $\left(\chi^{2}\right)$.

Berdasarkan tabel 1. dapat diketahui bahwa proporsi responden yang memiliki pengetahuan kurang dan tidak patuh dalam menggunakan APD adalah sebesar 92,3\% lebih besar jika dibandingkan dengan proporsi responden yang memiliki pengetahuan cukup dan tidak patuh yakni sebesar $63,2 \%$ dan responden yang memiliki pengetahuan baik dan tidak patuh dalam menggunakan APD yaitu sebesar 34, $4 \%$. Hasil uji Chi-Square $\left(\chi^{2}\right)$ diperoleh $p$ value $=0,001$. Artinya ada hubungan bermakna antara pengetahuan dengan kepatuhan penggunaan APD.

Berdasarkan teori safety triad dalam Notoatmodjo, S. (2010), Geller mengungkapkan bahwa untuk membentuk budaya selamat terdapat tiga komponen yang saling berhubungan satu sama lain dan harus dicapai yaitu people (orang), behaviour (perilaku), dan envirotment (lingkungan) yang disebut dengan safety triad. Komponen person terdapat beberapa faktor yaitu pengetahuan, kemampuan, keterampilan, kepandaian, motivasi dan kepribadian tenaga kerja.

Berdasarkan hasil penelitian (tabel 1), terdapat 1 orang petugas yang berpengetahuan kurang, tetapi patuh dalam penggunaan APD. Hal ini dikarenakan petugas tersebut pernah mengalami kecelakaan kerja ditempat kerja sebelumnya. Ada 12 petugas yang berpengetahuan cukup, tetapi tidak patuh dalam menggunakan APD. Berdasarkan wawancara dengan petugas tersebut, mereka menyatakan tidak nyaman dalam menggunakan APD, APD rusak atau hilang, dan pengawasan yang kurang dari pihak rumah sakit. Ada 11 petugas yang berpengetahuan baik, tetapi tidak patuh dalam menggunakan APD. Hal ini dikarenakan kurangnya kesadaran petugas, pengawasan dan ketegasan pihak RS. Selain itu, tidak adanya sanksi jika petugas tidak menggunakan APD. Hasil penelitian menunjukkan ada hubungan bermakna antara pengetahuan petugas IPSRS dengan kepatuhan penggunaan APD di RSUD Siti Aisyah Kota Lubuklinggau.

Tabel 2. Hubungan Perilaku dengan Kepatuhan Penggunaan APD

\begin{tabular}{|c|c|c|c|c|c|c|c|}
\hline \multirow{3}{*}{ Perilaku } & \multicolumn{7}{|c|}{ Kepatuhan Penggunaan APD } \\
\hline & \multicolumn{2}{|c|}{ Tidak Patuh } & \multicolumn{2}{|c|}{ Patuh } & \multirow{2}{*}{ Jumlah } & \multirow{2}{*}{ Prosentase } & \multirow{2}{*}{ p value } \\
\hline & Jumlah & Prosentase & Jumlah & Prosentase & & & \\
\hline Tidak Baik & 8 & 100 & 0 & 0 & 8 & 100 & \multirow{3}{*}{0,006} \\
\hline Baik & 27 & 48,2 & 29 & 51,8 & 56 & 100 & \\
\hline Jumlah & 35 & 54,7 & 29 & 45,3 & 64 & 100 & \\
\hline
\end{tabular}

Hasil penelitian ini tidak sejalan dengan penelitian yang dilakukan oleh Arifin dan Susanto, (2013) yang menyatakan bahwa tidak ada hubungan antara pengetahuan petugas dengan kepatuhan penggunaan APD. Hasil penelitian ini sejalan dengan Notoatmodjo, S, 2010) yang menyatakan bahwa pengetahuan merupakan salah satu faktor dalam komponen person pada teori safety triad yang akan mempengaruhi kepatuhan (Geller, 2001). Teori safety triad ini menjelaskan bahwa pengetahuan seharusnya memiliki hubungan yang signifikan dengan kepatuhan tenaga kerja dalam menggunakan APD. 


\section{Jurnal Aisyah: Jurnal Ilmu Kesehatan 2 (2) 2017, - 157}

Rizka Ayu Zahara, Santoso Ujang Effendi, Nurul Khairani

Berdasarkan hasil penelitian yang terangkum pada tabel 2 , terdapat 27 orang petugas yang berperilaku baik, tetapi tidak patuh dalam penggunaan APD. Hal ini dikarenakan kurangnya kesadaran petugas dalam penggunaan APD yang baik dan benar serta kurang menyadari bahwa tempat mereka bekerja sangat berisiko untuk menimbulkan terjadinya kecelakaan kerja dan penyakit akibat kecelakaan kerja. Hasil penelitian menunjukkan ada hubungan bermakna antara perilaku petugas IPSRS dengan kepatuhan penggunaan APD di RSUD Siti Aisyah Kota Lubuklinggau.

Berdasarkan teori safety triad dalam Notoatmodjo, S. (2010) Geller mengungkapkan bahwa untuk membentuk budaya selamat terdapat tiga komponen yang saling berhubungan satu sama lain dan harus dicapai yaitu people (orang), behaviour (perilaku), dan envirotment (lingkungan) yang disebut dengan safety triad. Faktor pada komponen behaviour yaitu persetujuan, pelatihan, pengenalan, komunikasi dan kepedulian yang aktif. Faktor envirotment adalah peralatan dan kelengkapan mesin, rumah tangga, suhu, teknik, standar dan prosedur operasional.

B.F. Skinner (1974) membantu mengubah fokus behaviorisme melalui percobaan yang dinamakan "operant condition" dan "reinforcement". "Operant condition" adalah setiap perilaku yang beroperasi dalam suatu lingkungan dengan cara tertentu, lalu memunculkan akibat atau perubahan dalam lingkungan tersebut. Yang dimaksud dengan "reinforcement" adalah proses dimana akibat atau perubahan yang terjadi dalam lingkungan memperkuat perilaku dimasa datang (Agustine, S. 2015).

\section{KESIMPULAN DAN SARAN}

Berdasarkan uraian dari di atas dapat ditarik beberapa kesimpulan diantaranya adalah terdapat hubungan yang bermakna antara pengetahuan dengan kepatuhan penggunaan APD $(p$ value $=0,001)$, terdapat hubungan antara perilaku dengan kepatuhan penggunaan APD ( $p$ value $=0,006)$. Disarankan kepada peneliti selanjutnya untuk meneliti tentang hubungan pelatihan, pengawasan, dan penerapan manajemen Kesehatan dan Keselamatan Kerja (K3) dengan penggunaan APD. 
Jurnal Aisyah: Jurnal Ilmu Kesehatan 2 (2) $2017,-158$

Rizka Ayu Zahara, Santoso Ujang Effendi, Nurul Khairani

\section{DAFTAR PUSTAKA}

Agustine, S. (2015). Perilaku penggunaan $A P D$ dan faktor-faktor yangb berpengaruh pada pekerja perusahaan jasa konstruksi sebuah studi kualitatif dengan pendekatan fenomenologis. Skripsi (Tidak diterbitkan). Depok: Universitas Indonesia.

Arifin, A. B., Susanto, A. (2013). FaktorFaktor yang Berhubungan dengan Kepatuhan Pekerja Dalam Pemakaian Alat Pelindung Diri (Apd) di Bagian Coal Yard RT X Unit 3 \& 4 Kabupaten Jepara Tahun 2012. Jurnal Kesehatan Masyarakat, 2 (1). Diunduh tanggal 18 Agustus 2017.

Buntarto. (2015). Panduan Praktis Keselamatan dan Kesehatan Kerja Untuk Industri. Yogyakarta: Pustaka Baru.

Hasyim, H. (2015). Manajemen Hyperkes dan Keselamatan Kerja di Rumah Sakit (Tinjauan Kegiatan Dan Keselamatan dan Kesehatan Kerja di Industri Sarana Kesehatan). JMPK Vol.08/No.02/Juni/2005.

Kemenkes R.I. (2010). Keputusan Menteri Kesehatan Republik Indonesia. No.1087 Tentang Standar Kesehatan dan Keselamatan Kerja di Rumah Sakit. Jakarta: Kemenkes R.I.

Notoatmodjo, S. (2010). Ilmu perilaku kesehatan. Jakarta: Rineka Cipta.

Putri, K; Denny, Y. (2014). Analisis Faktor yang Berhubungan dengan Kepatuhan Penggunaan APD. The Indonesian Journal of Occupational Safety, Health and Envirotment, 1 (1), 24-36.
Suma'mur. (2009). Higiene perusahaan dan kesehatan kerja (HIPERKES). Jakarta: Sagung Seto. 